DOI https://doi.org/10.36059/978-966-397-225-1-8

\title{
THE MEDITATIVE POETICS IN ART AND CULTURE AT THE BEGINNING OF THE THIRD MILLENNIUM
}

\section{Humeniuk Tetiana}

\section{INTRODUCTION}

We have considered the meditative poetics to be a topical issue as there is a rise of the new artistic phenomena, which are versatile, ambiguous, or even contradictory, and often very difficult to understand, interpret, and generalise. The art of the previous centuries clearly outlined certain artistic and stylistic trends, the original expression of the worldview, way of thinking (in particular, postmodernism). The culture of the first decades of the twenty-first century is fully perceived as a phenomenon of "commencement de siècle" - new, "beginning" as something new, the beginning of a new century, especially when it is a Millennium. This term is a kind of metaphor, a heuristic sign of the latest phenomena in world culture, a new "cultural dominant" (according to F. Jameson). Considering them, cultural and art historians are increasingly paying attention to meditative features. First of all, we are talking about works that have a certain static character, apoactivity, they form a kind of discourse, emphasise ambience, a certain way of "actions and thoughts".

Coming to this issue, the researchers note: "The chronological boundary between epochs will always be conditional, but it exists: turn of a new century inspires hope, and the end of the century inclines to sum up. "Commencement de siècle" term... is antinomic in comparison with the common definition "finde siècle" (end of the century) in humanitarianism, although the opposition of the end and beginning of centuries is relative and hardly constitutes the antithesis" ". It stands to reason that new cultural and artistic processes require a corresponding theoretical understanding, in particular, clarification, updating and enrichment of the research vocabulary for their adequate analysis and characteristics, for understanding what is natural and culture-oriented in them, and what is accidental and transient.

${ }^{1}$ Humeniuk T. K. (2017) Nove svitovidchuttia - "Sommencement de siècle" yak fenomen kultury: svitohliadni nastanovy i khudozhno-estetychni vymiry [New worldview "Sommencement de siècle" as a cultural phenomenon: worldviews and artistic and aesthetic dimensions]. Chasopys Natsionalnoi muzychnoi akademii Ukrainy imeni P. I. Chaikovskoho [Journal of Tchaikovsky National Music Academy of Ukraine], no. 4(37), p. 78. 
The concept of meditative style, in its general meaning, is widely used by researchers to characterise modern works, although they often "break" and significantly expand and transform the traditional meaning of this term, without denying its aesthetic essence. The purpose of the research is to distinguish between the meditative style term as a genre and meditation as a spiritual practice; to characterise the features in the works of the contemporary writers; to consider the levels of meditative style, to differentiate meditative art and those phenomena that are misclassified as meditative. In this regard, it is necessary to consider meditative style in art culture, generated by certain social and moral and psychological factors, to reveal its main characteristics and presenting features in works of art.

Not only musicologists, but also art historians, and philosophers research meditative style issues. There is L. Voievodina, Yu. Antonian, T. Anikina and M. Sofiienko, I. Kozlyk, L. Briukhovetska, O. Zubavina, S. Krymskyi, M. Buloshnykov, M. Kuznietsova, S. Pavlyshyn, A. Lunina, N. Zymohliad, and T. Cherednychenko. O. Zinkevych, I. Hamova, V. Drahanchuk, S. Proskurnia, Kh. Fleichuk who analyse meditative style in modern music. In particular, A. Chyharova considers the meditative concept of Alfred Schnittke in a choral concert with lyrics by Gregory of Narek; N. Kuznietsova notes that the musical culture of Europe in the second half of the 20th century is full of meditative style, which largely determined the "internal form" (G. Knabe) of the culture of this age. Musical phenomena that sometimes belong to various historical, cultural, aesthetic and stylistic traditions are combined with the idea of meditative style in its broad meaning: static sound "worlds" by G. Ligeti and "arabesques" by minimalists, experiments by K. Stockhausen and colourful pantheistic "canvases" by V. Silvestrov. Many names and schools were combined with the idea of meditative style, the art of the East and West was adopted, it combines "new sacredness" and Zen, introspective and lyricalcontemplative, postlude and musical statics, contemplation, prayer and reflection ${ }^{2}$.

\section{Meditative Style and Meditation}

Art historians and cultural scientists consider the elements of meditative style in works of art concerning their dialectical balance with reality, defining them as the most important figurative and structural correlates

${ }^{2}$ Kuznetsova M. V. (2007) Meditativnost' kak svoystvo muzykal'nogo myshleniya (Avet Terteryan, Arvo Pärt, Valentin Silvestrov) [Meditativeness as a property of musical thinking (Avet Terteryan, Arvo Pärt, Valentin Silvestrov)] (PhD Thesis). Moscow: Rossiyskaya akademiya muzyki imeni Gnesinykh. 
based on philosophical and aesthetic principles. Researchers distinguish between the phenomena of meditation and meditative style, determine the characteristic features of meditative style and the specifics of its interaction with the effective beginning in the conflict drama of modern works of art. However, most scientific works do not contain a comparative analysis of the etymology and ontology of the phenomena of meditation and meditative style, as well as their definitions in general, as if they do not distinguish between these concepts, often using them as invariants. Besides, the term "meditative art" is often applied to "pseudo-meditative" works related more to the experimentations of individual artists than to meditative style as a property of the artist's way of thinking.

Based on the individual ideas expressed in these works, we will consider the general and different between meditation and a meditative style, and also intrude our views upon this issue. The analytical material of the research consists of contemporary works of art of various genres, in which specific forms of meditative thinking of the East acquire a form of transculturality, they are assimilated on the Western basis in the works of artists of different nationalities, religions and aesthetic preferences. In general, the genesis of the concept of "meditative style" is associated with the practice of meditation, and in the theoretical aspect - with Eastern spiritual practices and their Western interpretations.

Meditation is a rather complex phenomenon that is interpreted in different ways. By its nature, it goes beyond the limits of materialistic philosophy and Western European logic, and understanding the meaning of meditation directly requires going deeper into the sphere of its appearance and habitual existence. Meditation mostly is associated with Buddhism and its doctrinal divisions (Taoism, Lamaism, Zen Buddhism, and some other religious systems). Researchers see analogues of Buddhist meditation in the spiritual practices of many world religions (or religious communities). Among them, in particular, there is the Orthodox "inner mind prayer", and its other names: "logos-meditation", or "Jesus Prayer"; exercises (that is, spiritual exercises of the Jesuit); "spiritual exercises" of Ignatius of Loyola; the meditation of Muslim Sufis; some practices of European schools of modern psychoanalysis, which are aimed at personality integration (the schools of C. Jung, E. Fromm). Music is used while meditation in Eastern religious practices (in Sufi Dhikr, Zen Buddhist Buddha Hack spirit and dharmakāya, although this is a separate topic of conversation), to focus, free yourself from vain emotions and thoughts.

Musical genres associated with meditation (IndianRaga) have been formed for many centuries in the East. Eastern human psychology associates them with the cult practice of contemplation. However, it would be a 
mistake to assume that raga is the same as meditation, although its musical settings are generally adequate to the internal psychological processes in the mind of a person in a state of Dhyana. At the same time, music in meditation, as well as mantras, contemplation of sacred images, ritual dances, is an auxiliary means of entering a meditative state.

Therefore, all types of meditation can not be found in "pure form" in the meditative sphere of modern art as a unique syncretism of world spiritual traditions. Of course, first of all, the condition of complete disengagement from all external influences is reduced, since the process of perception of art is a form of external influence. Of course, music, painting, or any other type of artwork contribute to self-concentration, concentration, but their influence can (with a certain reservation) be compared with the initial, "training" stages of meditation. Besides, when we perceive a certain work of art, we are time-poor, because we subconsciously set oneself up for the inevitable completion of this process. Meditation is continuous, it is not limited by any time settings (the meditator stays in Dhyana as long as he or she needs, returning to the active state only through perfectly worked-out volitional control or with the help of a guru). Therefore, the phenomena of meditation and art meditative style are not the same.

As for meditation as a process of thinking or deep inner concentration, aimed at relieving stress, activating the body's reserves, awakening creativity, intuition ${ }^{3}$, in the artistic sphere, this concept is used only in a metaphorical sense.

Taking into account the experience of Eastern authors, we will consider meditation regardless of world science achievements. First of all, we are talking about the widespread statement that the process of meditation cannot be fully reproduced in art. Consequently, regarding the influence of Eastern philosophical and religious teachings on modern world culture, the phenomenon of meditative style appears to be the result of the natural development of certain trends generated by the corresponding social and moral and psychological factors. In artwork, the meditative style becomes figurative static, non-contrast, in the reproduction of a state of disengagement and self-awareness.

So, at the beginning of the twentieth century (1918), Oswald Spengler sentenced European culture and civilization, and at the beginning of the twenty-first century, Serhii Krymskyi, a Ukrainian philosopher of culture,

\footnotetext{
${ }^{3}$ Rinpoche Y. M. (2015) Budda, mozg i neyrofiziologiya schast'ya: Kak izmenit' zhizn' $k$ luchshemu, prakticheskoe rukovodstvo [Buddha, the brain and the neurophysiology of happiness: How to change your life for the better, a practical guide], (trans. Dordzhe S.). Moscow: Orientaliya.
} 
expresses concern for the spiritual state of humanity with his "ever-living word". He notes that in the Third Millennium, world history proves the impossibility of its "horizontal" measurement, that is, progress understanding as to the harmonious development of civilization and culture. Analysing Oedipus The King tragedy, the scientist formulates the general cultural dominant of our time: humanity, like the ancient hero, “...he turns out to be blind to the mysteries of his own fate, its identity. He has knowledge that saves him from the monster... but he has no knowledge of the consequences of his life's actions, the knowledge of how not to become a monster himself...". Moreover, the scientist emphasises that the unique achievements of world civilization led to "... the unheard-of accumulation of dangerous cognitive results; the scientific blindness that, carried away by progress in solving the mysteries of nature, does not see the threat of moral degradation of people and their self-consciousness". ${ }^{4}$ At the turn of the eras, new "roads and crossroads of modern civilization" return": either the twenty-first century will be the century of spirituality, or the whole world, as warned O. Spengler, will be on the verge of a "mental age" and will soon turn into "petrified world"; what's more, it won't be (André Malraux). A. Spengler is called a prophet of the future, that is, our "present": "I see, long after a.d. 2000, cities laid out for ten to twenty million inhabitants, spread over enormous areas of country-side, with buildings that will dwarf the biggest of to-day's and notions of traffic and communication that we should regard as fantastic to the point of madness"6. And further: "all Civilizations enter upon a stage of appalling depopulation..."

A peculiar reaction of many artists to this state of culture was the search for new opportunities to understand the meaning of modern human existence, to show his life priorities, his departure from the external eventivity to the inner world. The attraction to this state - "...this is a means of translating the universe of the external world, being into the inner universe of the individual on an ethical basis, the ability to create an inner world, through which a person's self-identity is realised, his freedom from cruel dependence, from situations that are constantly changing. Spirituality,

\footnotetext{
${ }^{4}$ Krymskyi S. B. (2008) Pid syhnaturoiu Sofii [Under the signature of Sophia]. Kyiv: Vydavnychyi dim "Kyievo-Mohylianska akademiia", p. 709.

${ }^{5}$ This is the title of a collective monograph co-authored with S. Krymskyi: Paths and crossroads of modern civilization. K. 1998.

${ }^{6}$ Shpengler O. (2003) Zakat Evropy [The Decline of Europe] (vol. 2) (trans. Makhan'kova I.). Moscow: Ayrispress, p. 103.

7 Shpengler O. (2003) Zakat Evropy [The Decline of Europe] (vol. 2) (trans. Makhan'kova I.). Moscow: Ayrispress p. 108.
} 
in the end, leads to a kind of semantic cosmogony, connecting the image of the world with the moral law of the individual".

The use of specific imagery and stylistics to reproduce the inner feelings and states of a person in the late twentieth - especially in the early twentyfirst centuries is associated with the phenomenon of meditative style in art criticism. A modern Western person, turning to Eastern spiritual practices, compensates for his insensitivity to himself, which blocks the mechanisms of internal self-improvement. Thus, Jung noted that modern Westerners are better protected from crop failures, floods, and epidemics than from our pathetic spiritual inferiority, which is obviously not able to seriously resist mental epidemics.

In the scientific cultural and art studies apparatus, the concept of meditative style is quite legitimately widespread, although its combination with the term "poetics" is rather ambiguous for defining the analysis of poetic works that are quite peculiar in style and structure. The well-known Aristotle's work starts with "Our subject being Poetry, I propose to speak not only of the art in general but also of its species and their respective capacities; of the structure of plot required for a good poem; of the number and nature of the constituent parts of a poem; and likewise of any other matters in the same line of inquiry. Let us follow the natural order and begin with the primary facts"9. This situation today has not lost its relevance and scientific significance. In the context of the research problem, the ancient Greek thinker must cover too wide a range of problems - from the structure and development of literary genres and styles to the specifics of the artistic language and style of artwork.

Therefore, in contrast to the authors of the manual on cultural studies, in which the term "poetics" is considered as "...branch of literary studies, the science of the basic laws of the development of fiction as the art of writing" ${ }^{\prime 10}$. We follow the Aristotelian tradition in the interpretation of this term concerning all types of art as a set of aesthetic and stylistic features of a particular artistic phenomenon. After all, they constitute (according to Aristotle): "the essence of epic and tragic poetry, comedy and dithyrambic poetry, ... and most flute-playing and lyre-playing... as well as other related arts...,"ll.

${ }^{8}$ Krymskyi S. B. (2000) Filosofiya kak put' chelovechnosti i nadezhdy [Philosophy as the path of humanity and hope]. Kyiv: Kurs, p. 57.

${ }_{10}$ Aristotle (2018) Poetyka [Poetics], (trans. Ten B.). Kharkiv: Folio, p. 1.

${ }^{10}$ Hrytsenko T. B., Hrytsenko S. P., Kondratiuk A. Yu. (2007) Kulturolohiia [Culturology]. Kyiv: Tsentr navchalnoi literatury.

${ }^{11}$ Aristotle (2018) Poetyka [Poetics], (trans. Ten B.). Kharkiv: Folio, p. 1. 
To understand the poetics of meditative style as an artistic phenomenon, it is important to observe the philosophical "guru" of postmodernism, J. Derrida. Reflecting on the nature of language, developing a theory of philosophical discourse, he asks if philosophical discourse is normalised and to what extent it modalities? ${ }^{12}$ Linguists and philosophers constantly investigate in what way Aristotle's categories as a certain code of thinking, including artistic and aesthetic, are fundamental to the ontology (=beingness) and epistemology (+cognition) of the "world of culture" and later became categories not only of grammar, logic, and metaphysics but also the basis of Western scientific thought in general. Therefore, the question of how to use each specific term as a specific code of thinking is fundamental in the ontology (=beingness) and epistemology (+cognition) of the "world of culture".

Regarding the meditative poetics as an artistic phenomenon, which is quite popular and resonant due to its ambiguity, it distinguishes several levels. Considering them, it is important to emphasise that it is considered as 1) a specific property of the artist's way of thinking, a sign of artist's individual style; 2) one of the types of stylistics, a certain dimension of the structure, artwork structure, which is in the conflict-free "field". When analysing a particular artwork, the main focus is on conceptual philosophical, including ideological and religious ideas and their forms. Having discovered the ontology of meditation, its essence, signs, we project them on the phenomenon of meditative style in the artwork.

Any "translation" of a term or concept, which is from another cultural environment, does not provide (and cannot predict) its exact, and sometimes approximate, conceptual equivalents in other languages. It is right and relevant to define it in the latest philosophical dictionary as "the lexicon of untranslatability". According to French philosophers, each language provides an opportunity for its native speakers to use very specific opportunities for "philosophizing", due to the unique culture of the people. The Preface to the Ukrainian edition states: "...the "lexicon of untranslatability" is by no means simply "translated": in each particular case, the source text finds itself in a new linguistic and cultural environment, with its own presumptions and self-evidences, worldview and historical traditions, the spectrum of the known and unknown, the familiar and unfamiliar, and so on. Consequently, each translation of the "lexicon of untranslatability" became its linguistic and cultural adaptation - which in practice once again confirmed the correctness of the original cultural and

\footnotetext{
${ }^{12}$ Derrida J. (2012) Polya filosofii [Fields of Philosophy], (trans. Kralechkin D. Yu.). Moscow: Akademicheskiy Proekt.
} 
philosophical viewpoint, which, in fact, became the basis for creating the Dictionary $^{13}$.

Scientists also refer to examples of Christian meditation in the transcription of Hryhorii Skovoroda, who introduces the concept of "biblical symphony". This encourages us to turn to the translation of the key concept of ancient Indian culture, its semantic load in the process of translation into foreign cultural environments ${ }^{14}$. Thus, H. Skovoroda constructs a kind of philosophical dialogue based on the concordance of universal wisdom as a special form of the out-of-temple liturgy (Greek: leiturgia, leitos - social, public, and ergon - business, work). This is a symphony influence on meanings, words, and sayings that make up the content of the universal search for gradual excarnation, to metaphysical "awakening", to the highest spiritual goal. In the genre architectonics of H. Skovoroda's works, a new understanding of the essence of being "... comes in the form of congregational singing-meditation by the voice of the heart, not "natural language" - sing that is a tune (which means the Greek word "symphony") twins hearts with the Word of God...". ${ }^{15}$ The keynote of the Ukrainian thinker's work, as well as the organising element of his poetic texts, is the theme of human self-knowledge, which is equivalent to God-Knowledge: "You do not know you if you do not know God" keeping with the understanding of the ultimate goal of meditation as such, because all meditation practices are aimed at revealing the real essence of the person, its true self. In the secret dialogue of man with God, in the direct meeting of the infinite freedom of God and the limited freedom of man, lies the essential difference between Christian meditation and meditation in the Eastern traditional teachings, which by reflection and contemplation of the world free themselves from passions.

The general points in artworks that this term is associated with allow us to understand exactly what artistic and figurative features are inherent in meditative style. For the "urbanized" and "mechanized" Western man,

${ }^{13}$ Cassin B. (ed.) (2009) Yevropeiskyi slovnyk filosofii: leksykon neperekladnostei [European dictionary of philosophies: a lexicon of untranslatability] (vol. 1). Kyiv: Dukh i Litera, p. 8-9.

${ }^{14}$ Sulyma V. (2013) Do pytannia pro zhanr tvoru Hryhoriia Skovorody "SVMFONIA, narechennaia Knyha Askhan o Poznaniy y samaho sebe" [On the question of the genre of the work of Gregory Skovoroda "SVMFONIA, the bride The Book of Askhan about Poznan and himself']. Pereiaslavski Skovorodynivski studii [Pereiaslav Skovoroda researches], vol. 2, pp. 111-117.

${ }^{15}$ Marchenko O. V. (2000) Filosofskiy dialog G. S. Skovorody kak vnekhramovaya liturgiya [Philosophical Dialogue of G. S. Skovoroda as a Liturgy outside the Church]. Filosofskaya gazeta [Philosophical Newspaper], no. 1.

16 Skovoroda H. (2011) Povna akademichna zbirka tvoriv [Complete academic collection of works], (ed. Ushkalov L.). Kharkiv: Maidan, p. 300. 
alienated from himself, from nature, from God, the East appears as a kind of idealised world, the personification of a harmonious universe in which ethical self-improvement and self-concentration reigns. As E. Fromm explains, all Eastern religious and philosophical teachings significantly exceed the wisdom of Western thinkers with their ideas about man and the meaning of his existence: “... in the East, there is no concept of a transcendental father-Saviour... Rationality and realism are inherent in Taoism and Buddhism to a greater extent than the religions of the West. In the East, a person voluntarily, without compulsion, joins the "awakened", because everyone is potentially capable of awakening and enlightenment. This is why Eastern religious thinking, embodied in Taoism, Buddhism, and Zen Buddhism as a synthesis, is so important to Western culture today." Further, he notes that thanks to the wisdom of the East, a person has the opportunity ".. to find an answer to the question of the meaning of his existence, and this answer basically does not come into fundamental contradiction (emphasised by us - T. H.) with both traditional JudeoChristian ideas, on the one hand, and with the values of modern man rationality, realism and independence, on the other. Thus, incredible as it may seem, Eastern religious ideas are closer in spirit to Western rational thinking than Western ones" $"$.

\section{Meditative Style as a Means of Cognition of Man and the World}

Meditative artworks are deeply mediated, emotionally detached, and full of restraint. If we compare with music, these features are not related to jazz, but rather to "ambient", a style of modern electronic music that is characterized by unobtrusive, background sound. The question is quite logical: What does such absence, non-participation, and disengagement mean? Is the meaning of meditative style limited to total negation?

To understand the meaning of this phenomenon, let's turn to modern Asian cinema, a unique phenomenon in the world art of the twenty-first century. Disengagement from everything external, self - concentration, a kind of "exclusion" from the general process, transition to a different plane of perception, where completely different laws of time and space operate - all this is inherent in it as a meditative art. So, the film "Sympathy for $\mathrm{Mr}$ Vengeance" by the famous South Korean film director Park Chan-wook, is about an angel girl of incredible beauty, unusually bright and cheerful, who is accused of kidnapping and killing children. And the constant flashbacks, the

17 Fromm E. (2013) Dzen-buddizm i psikhoanaliz. Psikhoanaliz $i$ religiya. Krizis psikhoanaliza [Zen Buddhism and Psychoanalysis. Psychoanalysis and Religion. The crisis of psychoanalysis], (trans. Kulagina-Yartseva V., Yakovleva A., Grossman E.). Moscow: Big-Press, p. 6. 
girl's voice-over who sympathetically tells this sad, tragic and paradoxical story, gradually enter a plea of not guilty of the heroine. Considering this work as an example of meditative art, it is worth emphasising that it is not characterised by emotional intensity, explosive, contrasting psychological states. It does not cause any aggressive reactions, on the contrary, it encourages you to listen, look closely, and focus on details.

Focusing on these features of the psychological influence of meditative art, it is impossible to avoid comparison with the phenomenon of meditation as such, not to point out the common features for them. Therefore, the heroine's daughter, who lives in a respectable family and does not even know about the existence of her birth mother, lies on an old tree, looking up to the blue sky, where the clouds gradually turn into the words: "you don't have a mother." Moving air from passing car, out which a slender and extremely beautiful woman gets, blows away the word "don't", and a new expression is formed in the sky: "You have a mother."

To understand the poetic philosophy of meditative art, one should also take into account such a feature of consciousness as the sublimation of the "event series". We are talking about the manifestation of certain senses in meanings that were perceived quite differently until recently or under other circumstances. It is important that the meditative art of "the beginning of the twenty-first century" 18 against the background of metaculture (or transculture, ostculture, postpostmodern), in a crisis, powerlessness, alienation gives a chance to avoid escapism, escape to "the tower of poetic alienation" in a world of illusions, and fantasies.

The horrific murders of innocent children by a seemingly "decent" teacher leave everyone with a difficult choice: rely on a legal court or resort to the revenge of the victims. In fact, an objective court is not able to comprehend the full extent of this tragedy, so a knife strike is perceived as a fair and appropriate act of "grief-stricken" parents. However, one detail draws attention: there is the over-voice of the heroine's daughter, who helps to complete the long path of love healing with compassion and forgiveness.

Disengagement, self-concentration, a kind of "exclusion" from the general process (if we are talking about meditative style within the confines of conflict drama), the transition to a different plane of perception, in which completely different, new laws of time and space operate - all these moments are common to both meditation and meditative style. However, creativity is always the art of emotions. Therefore, all meditation elements

${ }^{18}$ Humeniuk T. K. (2017) Nove svitovidchuttia - "Sommencement de siècle" yak fenomen kultury: svitohliadni nastanovy i khudozhno-estetychni vymiry [New worldview "Sommencement de siècle" as a cultural phenomenon: worldviews and artistic and aesthetic dimensions]. Chasopys Natsionalnoi muzychnoi akademii Ukrainy imeni P. I. Chaikovskoho [Journal of Tchaikovsky National Music Academy of Ukraine], no. 4(37), pp. 78-98. 
can not be found in "pure form" in the meditative sphere of modern art as a unique syncretism of world spiritual traditions. Of course, first of all, the condition of complete disengagement from all external influences is reduced, since the process of perception of art is a form of external influence. Of course, music, painting, or any other type of artwork contribute to selfconcentration, concentration, but their influence can (with a certain reservation) be compared with the initial, "training" stages of meditation. Also, when we perceive a certain work of art, we are time-poor, because we subconsciously set oneself up for the inevitable completion of this process (as result or break).

Meditative style is associated with a subjective and personal image of the world picture. On the one hand, this subjective principle can be in dialectical subordination with the reflection of the objective, real world, that is, it can represent opposite spheres: idealistic - realistic. In a sense, this is typical for romantic works, in particular musical ones, in which the opposition of the objective and the subjective is embodied in the conflict drama. On the other hand, meditative style can also be presented in its "pure form", as lyriccontemplative, without any hint of conflict. Under such conditions, it is usually associated with a lyrical utterance, thematically combined with a retrospective. We are talking about the intention to comprehend the connection of times, to return to art the harmony of a spiritual intonation mode, to contrast the moral and ethical values of the past with the spiritual crisis of our time.

The retrospect theme arranges reflections on the future of humanity's existence in the modern globalised world. The danger of turning this existence into an illusion is not due to new technologies. The spread of it in society is shown at least by the fact that many Western media think the question "To be or not to be?" to be the main one. Indeed, for many centuries, man purposefully and consistently destroyed his connections with the upper world, striving to become the master of his life and the universe as a whole. Although man just became dependent on social, political and economic circumstances, destroying the main pillars of life. All this could not pass completely. Losing the ontological basis, a man gave illusory to his life and the surrounding reality, until virtual reality began to claim equality, or even superiority over the reality of human existence finally. For a reason that art, which is a barometer (although not too sensitive) of the human condition, completes the problem of escaping the danger of total virtualisation. A new technology that allows communicating every second does not actually bring people together but creates a virtual space of "accumulation of loneliness", the illusion of communication, the illusion of life.

Among many recent art phenomena, works, containing a retrospective meditative aspect, where time appears almost as the main object of 
comprehension and reflection, attract attention. This is also due to the specific characteristics of the poetics of such artworks: the author's peculiar intonation, introspection, inwardness, significant semantic load, thematic and plot integrity, which gives originality. Time is really one of the most mysterious phenomena, closely connected with being, and this has always been keenly felt and artistically reflected by artists, in particular, F. Dostoyevsky believed that time is the relation of being to non - being". From the creation ("co-creation") of the world, artistic creativity and the movement of time do not stop, just as life-existence does not stop. Works' authors through the meditative poetics try to somehow slow down, stop time, turn back or completely abandon it.

Retrospect is a specific means of expressing a subjective psychological state in the work of Apichatpong Weerasethakul, who is a representative of the world's most famous new wave Thai cinema. In his film "Syndromes and a Century" (2006), the lyricism of the author's design concerns the image of the same circumstances, events, and characters in a double dimension - in the twentieth and twenty-first centuries. The "event series" gradually shifts in time, but no fundamental changes occur. The idea of reincarnation, which is repeatedly heard in the film (essence - spirit, soul - eternal, unchangeable, form - eternal) appears as the antithesis of speed, processability and is perceived as a psychological reaction to the general chaos, modern pace, rhythms, and speed. The director does not use a negative assessment of modernity. The whole world is the existence and coexistence of times. Meditative retrospection makes it possible to avoid any assessment, choose self-sufficient observation, eventfulness, contemplative stay, move away from the "great brain" of the general state, turn to the smallest psychological details, sketches of the countryside as a concentration of traditional knowledge $e^{19}$.

Artistic images in meditative art have common features. Meditative imagery is located in its "virtual reality", in a world that lives according to special laws that are adjusted by specific norms of time: meditative time is that time beyond that researchers define in different terms - "zero time", "time of contemplation", "stopped time", "time vacuum". They are generated by apoactivity, uniformity, the solidity of "themes" and extension of internal processes, "muted" and "shaded" emotions.

From this point of view, Weerasethakul's film story "Uncle Boonmee Who Can Recall His Past Lives" (2010) is meaningful. This is the first Thai film that won the Palme d'Or. It combines the themes of "the death of cinema", the

19 Ferrari M. (2012) Primitive gazing: Apichatpong Weerasethakul's sensational inaction cinema. Storytelling in World Cinemas: Forms, (ed. Khatib L.). New York: Columbia University Press, pp. 165-176. 
incurable disease of the hero and his memories of his past lives. Weerasethakul's story is not linear, it is full of rhetorical figures, does not have a cause-and-effect relationship, and contains the simultaneous coexistence of alternative storylines, analogies, associations, and the overlap of different time periods. The director observes the world of incomplete selfhood, identity, consonance and echo of memories, feelings in the consciousness of one subject or several as if he is watching from the sidelines.

Meditative art is not sensual, not pathetic, it lacks any extreme emotions. Of course, one cannot say that the meditative art does not have an emotional impact on a person at all. However, we are talking about emotions of the highest degree: beauty gazing and moral and aesthetic pleasure; experiences caused by the appeal to the spheres of Inviolable Harmony - peace and quiet; calm and relaxation, release from feelings of anxiety, tension, internal discomfort. This can be compared to the state of "accommodation of opposites" that Zen Buddhists achieve with the help of appropriate techniques. Modern Asian cinema illustrates the originality of artistic thinking convincingly. Its representatives take part in international film festivals, winning prestigious awards, each of their films gets a rating among the best films, critics and scientists write about them. Their authors do not limit themselves to formal experiments but offer an original worldview and a unique author's style. They reflect the spiritual state of modern Western and Eastern society, reproducing the worldview of an individual who is struggling to maintain his autonomy between the Scylla of Western globalisation and urbanisation and the Charybdis of national self-defining and the intellectual and poetic traditions of the East.

Hence, meditative style is an artistic phenomenon that became widespread in the world of art at the turn of the Millennium. It is generated by the inner need of artistic thinking to move away from the external eventfulness, to delve into the sphere of contemplation of the modern world in its all-consuming timelessness, which does not imply any randomness, events, movements, details for the character. Such works do not even balance on the edge of farce and tragedy, comedy and drama - they are in all the elements at once, appearing in front of the audience each time in a different form. They are characterized by stylistic retrospect, lyrical statement, static, conflict-free, adynamic, emotional and psychological reactivity, aloofness, aprocessality, imaginative integrity and thematic uniformity, focus on the elements of the whole. Their stylistic features are repeatability, the openness of form, virtuality of space, slowness of narration and plot dynamics. Meditative disengagement, contemplation, is not really a retreat into speculative metaphysical realms, but disengagement from everything that suppresses the individual. After all, such a standpoint expresses the presence of a person, and not an abstract, "timeless" one, but a 
"concrete person" with a specific environment and culture. The meditative style mustn't level the individuality of the artist's creative thinking, but rather emphasises his stylistic originality, aimed at showing the self-worth of a person, his individuality, "privacy" and "absence", as the poet J. Brodsky said in his Nobel speech ${ }^{20}$. In addition, thanks to the growth of technology, today, art has become not only accessible to anyone and in any place, but its perception has also reached the level of personal, private experience, metaphorically speaking, it has disappeared among people. The individuality of perception, and even more - the acceptance and creation of art by each person for their own comfort and pleasure, bond them over meditative style. After all, we are talking about a special state of the individual experience of personal feelings and direct response of the soul.

The analysis made it possible to reveal the nature of meditative style in art culture, generated by certain social and moral and psychological factors, its main characteristics, to identify the difference between meditation as an artistic phenomenon and meditation associated with spiritual practices, to emphasise the relevance of the problem under study, which constantly attracts the attention of philosophers, cultural scientists and art historians.

\section{SUMMARY}

The relevance of the research topic is due to the need to prove the research vocabulary for comparable analysis and description of the latest artistic phenomena in the culture of recent decades, for their theoretical understanding and definition. Modern cultural and art historians pay attention to the concept of meditative style, although sometimes there are inaccuracies in the use of this term. The purpose of the article is to consider meditative style in art culture, generated by certain social and moralpsychological factors, its main characteristics, to identify the difference between meditation as an artistic phenomenon and meditation that is not related to art. The research methodology consists of methods of theoretical analysis and interpretation. Meditative style as an artistic phenomenon became especially widespread in world art at the turn of the Millennium. It is generated by the inner need for artistic thinking to move away from the external eventfulness, to delve into the sphere of contemplation, knowledge of the modern world. These artworks are characterised by stylistic retrospect, lyrical statement, static, conflict-free, adynamic, emotional and psychological reactivity, aloofness, aprocessality, imaginative integrity and thematic uniformity, focus on the elements of the whole. Their stylistic features are repeatability, the openness of form, virtuality of space, slowness

20 Brodskiy I. (1987) Nobelevskaya lektsiya [Nobel lecture]. Retrieved from: http://lib.ru/BRODSKIJ/lect.txt (accessed 28 September 2020). 
of narration and plot dynamics. The scientific novelty of the article consists in revealing the nature of the phenomenon under study, determining its structure and typical features, and analysing specific artistic forms of meditative style in works of modern art. Conclusions: meditative disengagement, contemplation does not mean going into speculative metaphysical spheres but indicates disengagement from everything that suppresses the individual. This standpoint expresses the presence of a person, and not an abstract, "timeless" one, but a "concrete person" with a specific environment and culture. It is important that meditative style does not level the creative thinking of the artist, but emphasises its semantic and stylistic originality, aimed at showing the self-worth of a person, his individuality.

\section{REFERENCES}

1. Aristotle (2018) Poetyka [Poetics], (trans. Ten B.). Kharkiv: Folio. (in Ukrainian)

2. Boehler N. (2011) The Jungle as Border Zone: The Aesthetics of Nature in the Work of Apichatpong Weerasethakul. ASEAS - Austrian Journal of South-East Asian Studies, vol. 4, no. 2, pp. 290-304.

3. Brodskiy I. (1987) Nobelevskaya lektsiya [Nobel lecture]. Retrieved from: http://lib.ru/BRODSKIJ/lect.txt (accessed 28 September 2020).

4. Cassin B. (ed.) (2009) Yevropeiskyi slovnyk filosofii: leksykon neperekladnostei [European dictionary of philosophies: a lexicon of untranslatability] (vol. 1). Kyiv: Dukh i Litera. (in Ukrainian)

5. Derrida J. (2012) Polya filosofii [Fields of Philosophy], (trans. Kralechkin D. Yu.). Moscow: Akademicheskiy Proekt. (in Russian)

6. Ferrari M. (2012) Primitive gazing: Apichatpong Weerasethakul's sensational inaction cinema. Storytelling in World Cinemas: Forms, (ed. Khatib L.). New York: Columbia University Press, pp. 165-176.

7. Fromm E. (2013) Dzen-buddizm i psikhoanaliz. Psikhoanaliz i religiya. Krizis psikhoanaliza [Zen Buddhism and Psychoanalysis. Psychoanalysis and Religion. The crisis of psychoanalysis], (trans. Kulagina-Yartseva V., Yakovleva A., Grossman E.). Moscow: Big-Press. (in Russian)

8. Hrytsenko T. B., Hrytsenko S. P., Kondratiuk A. Yu. (2007) Kulturolohiia [Culturology]. Kyiv: Tsentr navchalnoi literatury. (in Ukrainian)

9. Humeniuk T. K. (2017) Nove svitovidchuttia - "Sommencement de siècle" yak fenomen kultury: svitohliadni nastanovy i khudozhno-estetychni vymiry [New worldview - "Sommencement de siècle" as a cultural phenomenon: worldviews and artistic and aesthetic dimensions]. Chasopys Natsionalnoi muzychnoi akademii Ukrainy imeni P. I. Chaikovskoho 
[Journal of Tchaikovsky National Music Academy of Ukraine], no. 4(37), pp. $78-98$.

10. Krymskiy S. B. (2000) Filosofiya kak put' chelovechnosti i nadezhdy [Philosophy as the path of humanity and hope]. Kyiv: Kurs. (in Russian)

11. Krymskyi S. B. (2008) Pid syhnaturoiu Sofii [Under the signature of Sophia]. Kyiv: Vydavnychyi dim "Kyievo-Mohylianska akademiia". (in Ukrainian)

12. Kuznetsova M. V. (2007) Meditativnost' kak svoystvo muzykal'nogo myshleniya (Avet Terteryan, Arvo Pärt, Valentin Silvestrov) [Meditativeness as a property of musical thinking (Avet Terteryan, Arvo Pärt, Valentin Silvestrov)] (PhD Thesis). Moscow: Rossiyskaya akademiya muzyki imeni Gnesinykh.

13. Marchenko O. V. (2000) Filosofskiy dialog G. S. Skovorody kak vnekhramovaya liturgiya [Philosophical Dialogue of G. S. Skovoroda as a Liturgy outside the Church]. Filosofskaya gazeta [Philosophical Newspaper], no. 1.

14. Rinpoche Y. M. (2015) Budda, mozg i neyrofiziologiya schast'ya: Kak izmenit' zhizn' $k$ luchshemu, prakticheskoe rukovodstvo [Buddha, the brain and the neurophysiology of happiness: How to change your life for the better, a practical guide], (trans. Dordzhe S.). Moscow: Orientaliya. (in Russian)

15. Shpengler O. (2003) Zakat Evropy [The Decline of Europe] (vol. 2) (trans. Makhan'kova I.). Moscow: Ayrispress. (in Russian)

16. Skovoroda H. (2011) Povna akademichna zbirka tvoriv [Complete academic collection of works], (ed. Ushkalov L.). Kharkiv: Maidan. (in Ukrainian)

17. Sulyma V. (2013) Do pytannia pro zhanr tvoru Hryhoriia Skovorody "SVMFONIA, narechennaia Knyha Askhan o Poznaniy y samaho sebe" [On the question of the genre of the work of Gregory Skovoroda "SVMFONIA, the named Book of Askhan about knowledge and himself"]. Pereiaslavski Skovorodynivski studii [Pereiaslav Skovoroda researches], vol. 2, pp. 111-117.

Information about the author: Humeniuk Tetiana orcid.org/0000-0001-9210-6424 Doctor of Philosophy, Professor Kyiv National University of Culture and Arts 36, Ye. Konovaltsia St., Kyiv, 01133, Ukraine 